\title{
Lateral
}

Journal of the Cultural Studies Association

\section{Review of The Anti-Capitalist Chronicles by David Harvey (Pluto Press)}

by Austin Gallas | Book Reviews, Issue 10.1 (Spring 2021)

ABSTRACT The Anti-Capitalist Chronicles is a collection of accessible, loosely connected essays by influential Marxist geographer David Harvey. Based on episodes of Harvey's podcast of the same name, the book tackles topics related to the contemporary and historical crises of global capitalism. In nineteen brief, topical chapters, Harvey appropriates and reimagines Marxian categories and anti-capitalist frameworks of various kinds in order to report on the changing shape of global capitalism considered as a historically distinct social formation, the internal logics and contradictions which govern capital's movements in the world, and the obstacles to be overcome by socialist politics.

KEYWORDS capital, geography, global capitalism, political economy, socialism

The Anti-Capitalist Chronicles. By David Harvey. London: Pluto Press, 2020, 240 pp. (paperback) IBSN 9780745342092. US List: \$19.95.

David Harvey is perhaps the world's best-known living Marxist intellectual. Harvey has for decades introduced audiences around the globe to accessible analyses of global capitalism. A senior scholar in his field of geography and author of more than two dozen books, including Seventeen Contradictions and the End of Capitalism (2014) and Marx, Capital, and the Madness of Economic Reason (2017), Harvey's articulation of neoliberalism as a class project is well known by scholars across the humanities and social sciences. His open-access lecture series on volumes 1 and 2 of Marx's Capital (and, more recently, the Grundrisse) have contributed to the wave of popular and scholarly interest in Marx's critique of political economy which has followed in the wake of the Great Recession.

Harvey's latest public-facing effort, The Anti-Capitalist Chronicles (2020), offers readers two things. It contains useful commentaries on the crises of global capitalism and the socialist possibilities opened up in the contemporary conjuncture. But it is also a handy portal into some of the most exciting realms of Harvey's intellectual output. Readers already familiar with Harvey's work will appreciate how he revivifies concepts and interventions from various periods in his career, using them to weave together insightful, unfamiliar commentaries on important matters, from financialization to urban development to geopolitical and military contests. Newcomers to Harvey's work are sure to find in the Chronicles ample incentive to begin the long and fruitful journey through his prodigious oeuvre. Educators will be pleased to encounter a book constructed with them in mind.

The basic premise of the book - that global capitalism is facing a number of existential crises, many of which are products of capital's own internal contradictions-will surely resonate with many readers who have lived through the rolling disasters of 2020. But there is a secondary thesis running through the book which is equally important: that socialists 
need to arrive at a more holistic appreciation of the obstacles in the path of anti-capitalist programs. To be successful, says Harvey, socialism will have to "negotiate a knife-edge path," for, on the one hand, the existing systems for distribution and provision seem "too big to fail," while, on the other hand, these same systems are breaking down under the weight of their own contradictions, and are foreclosing on the future by compromising the possibility of harmonic relations between humanity and the natural world (11).

The book is composed of a series of thematic essays on various urgent theoretical, historical, and contemporary concerns. Some chapters, like those on the resurgence of anti-austerity politics in Chile and China's rising significance within the global economic order, distill and reinforce insights Harvey has been writing about for decades. Other chapters, such as the one on anti-capitalism in the time of COVID-19, engage in speculative commentaries on geopolitical, environmental, and technological tensions that are fluid and still unfolding.

Chapters can be broadly categorized into three areas: how global capitalism works and how it fails, the internal logics and contradictions of a capitalist economy, and the challenges and radical potentialities involved in the creation of socialist alternatives. Each chapter tends to emphasize one theme over the rest, even as these three themes often blur together in significant ways.

Chapters $1,7,8,11,12$, and 14 focus on various crises within the actually existing global capitalist system. In Chapter 8, a sprawling narrative takes us from the opium wars in China to the post-crisis austerity politics in today's Greece. Harvey retools some of his bestknown categories like the "spatial fix" to analyze the shape of the modern global capitalist system and the historical processes which played parts in its construction. In Chapter 14, he appropriates Marxian critiques of the endless growth syndrome inherent to industrial capitalism to offer a nuanced analysis of the political-economic origins of the carbon dioxide buildup driving catastrophic climate change.

In chapters $2,3,4,10,13$, and 15 , the emphasis is on the internal logics and contradictions of capital itself, as well as on the mainstream economic theories that obscure these logics and contradictions. While the level of analysis in these chapters tends towards the theoretical, these chapters offer more than abstract ideas. They underline the real-world implications of the internal laws of motion natural to industrial capital. In chapter 13, for instance, Harvey deploys value theory to elaborate the implications of the growth of the service economy and new forms of consumerism to the composition of the working classes in de-industrialized nations like the United Kingdom and the United States.

The third group of essays, consisting of chapters $5,6,16,17,18$, and 19 , concerns the challenges facing anti-capitalist projects. Harvey considers possible routes along which anti-capitalist transformation might proceed, including opportunities which might be seized by workers situated across various geographic and national contexts. In chapter 6 , Harvey argues that socialist politics must be concerned with the protection and development of individual, as well as collective, freedoms.

In the hopes that it will be taken up by reading groups around the world, the book's editors, Jordan T. Camp and Chris Caruso, have worked to make it as friendly as possible to divergent learning environments. For example, discussion questions and additional reading suggestions are provided for each of its nineteen chapters. 
Though less elaborate than some of Harvey's other scholarly productions, Chronicles is nonetheless a welcome addition to the library of anyone working to understand the possibilities and theoretical nuances of contemporary anti-capitalist politics. It offers essential, timely commentaries on subjects of the highest significance to the present and future shape of global capitalism. Best of all, it does so in a charming, approachable waya rare and commendable feat.

\section{Author Information}

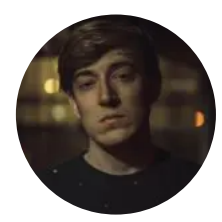

\section{Austin Gallas}

Austin Gallas is a doctoral candidate in Cultural Studies at George Mason University. His research explores bourgeois police reform, undercover surveillance, and the political economy of prostitution in Progressive-era New York City through a Marxist lens. He is a member of the Cultural Studies Association.

View all of Austin Gallas's articles.

\section{Article details}

Austin Gallas, "Review of The Anti-Capitalist Chronicles by David Harvey (Pluto Press)," Lateral 10.1 (2021).

https://doi.org/10.25158/L10.1.27

This content is licensed under a Creative Commons Attribution-NonCommercial 4.0 International License. Copyright is retained by authors.

Lateral is the peer-reviewed, open access journal of the Cultural Studies Association.

ISSN 2469-4053 